\title{
NEW MEDIA, OLD ARTISTRY: THE ADAPTATION OF YORÜBÁ FOLKTALE NARRATIVE STRATEGIES IN VIDEO FILMS
}

\author{
Adekemi Agnes Taiwo \\ Ekiti State University, Nigeria
}

\begin{abstract}
The argument of this study is that Yorùbá people continue to keep alive and sustain their society's oral folkloric tradition and verbal art despite the changes undergone by Yorùbá folktales that have passed into written form and other (new) media. Verbal arts educate, reflect and promote culture, as well as, their well-known capacity to instil moral decency in a young audience. This paper explores the adaptation of Yorùbá folkloric form in film. The audience memory is reawakened through the conservation and propagation of folktale into drama form in the film, Ijàpá and Àjàntálá. İjàpá (tortoise) is well known for its trickish behaviour and nature while Àjàntálá is also known for his vicious behaviour. Their character was worn into human beings (artiste) to teach society moral lessons. These Yorùbá movies İjàpá and Àjàntálá were adapted from Yorùbá folktales to examine issues and themes that are germane to contemporary society. İjàpá was produced in 2011 while Àjàntálá was produced in 2015. The theory of intertextuality which is the way books, songs, films are linked or associated to one another is adopted for the research.
\end{abstract}

KEYWORDS: YORÙBÁ ORAL FOLKTALE, ADAPTATION, INTERTEXTUALITY, FILM

\section{Introduction}

Video film is arguably one of the most popular modes of cultural expression in Nigeria especially among the Yoruba of the South-West Nigeria. Today, Yorubá video film ${ }^{1}$ has become a form of entertainment, relaxation and an avenue for defusing tension, releasing emotion and has gradually replaced other forms of entertainment such as the cinema, television and other stage drama in the society. The films are well conflated with folkloric elements that are giving them a unique cultural status. However, revolving around events which are espoused within the modern era, the story enjoys a meticulous blend of old and new, ancient and modern, in a unique way. The appropriation of popular culture by the fiction film in Africa creates a movement away from western film language and establishes an African narrative mode. Diawara (1988:8) corroborates this assertion by affirming that 'African film makers have deviated from foreign film culture by making use of some

1 Cinema film refers to movies of an artistic or educational nature shown in a theatre for public entertainment while video film refers to a film recorded on a video cassette for home use. 
cultural elements within their culture'. Ellapen (2012:45) comments that Diawara in his book $^{2}$ 'argues that Nollywood is important to African culture and life and provides stories of "mobility". This means the Nigerian film industries (including Yorùba film makers) serve as means of promoting their cultural heritage. Also, Ureke and Tomaselli (2017) in their own view explore how 'African Cinema' can be examined in terms of a film services framework which includes both industrial criteria and ideological shifts as a way of deepening screen media studies in search for a more holistic value chain framework. The study of Yorùbá folktale presentation on the screen serves this purpose. Folktale which is part of the features of Yorùbá oral literature is well entrenched in the films chosen for our analysis.

Yorùbá video film serves as a mirror to the society through which aspects of Yorùbá cultures including folktales are revealed to the world, and the ills of that society are exposed and corrected. Commenting on the preservation of culture in Africa, Franz (1998) opines that culture played a very significant role in the struggles of African countries against colonialism and exploitation. He says further that songs, dances and ritual drama mobilised people to understand and reject their colonial situation. It is a fact that African cultural expression has contributed in no small measure to shaping and strengthening African just as the transposition of folktale as part of African oral traditional expression has done as rightly observed in our analysis. Akínyẹmí (2011:32) observes that 'one common feature of African literature, irrespective of its language of expression, is the significant presence of materials from oral tradition'. This is now true of African film especially Yorùbá film where oral traditions predominantly feature in its narratives. Mgbejume (1989) also support the statement when he states that' Nollywood is a vehicle through which Nigerain cultural heritage is represented' Adésínà (1992:170) advocates that 'film should be employed to complement the service of moral re-armament in Nigeria'. She argues that prior to western education; Nigeria had a rich cultural heritage, a unique judicial system and a well-orchestrated social order. All these were brought about through the use of folklores, myth, legends and a hierarchy of governmental rules, respect for elders and constituted authorities. Adésínà further posits that 'all these virtues have been ended by western modernism; requiring urgent rearmament of our cultural harmony'. There is craze for wealth, moral bankruptcy and other social vices in the society; she suggests that the Nigeria film industry should be repositioned to change this downward moral trend and affect the rearmament of the society.

Oláyíwọlá (2011:222) also corroborates this observation, saying 'this view may be supported with the fact that African art is a functional art; it is primarily anchored on its didactic value'. The moonlight tales of the Yorùbá, incorporated into film will therefore not neglect the issue of morality while at the same time providing a highly enriching form of entertainment. The Yorùbá folktales are primarily entertaining but covertly and systematically address important and salient social, psychological, political, economic and environmental issues. Many scholars have worked on Yorùbá folktales. Akinyemi (2004) 
exposes the different moral teachings of Yorùbá folktales to children. Olayiwola (2011), in his study, suggests that the Nigerian film industry should develop an indigenous film language through a fusion of traditional story telling forms and conventional film codes while Usman et al (2013) examine the role of folktales employed in the making of Hausa movies (Nollywood). Their research analyses the plots of some selected Hausa movies with a view to examining the significance of folktale in film production. Olarinmoye (2013) dwells on the images of women in Yorùbá folktales, analyses the projection of women in Yorùbá folktales in order to identify what the authentic Yorùbá gender ideology is, with the purpose of putting into perspective the construction of women and the discourse of development. Akinwumi (2014) examines how post-modernist material and immaterial culture have influenced the literary and cultural values of Yorùbá folktales. Akanbi (2014) also focuses on the moral values of folktales. This study therefore answers the call to reposition the Nigerian film industry towards the rejuvenation of the moral rearmament of the society by exploring how the Yorùbá video film producers incorporate or adapt the Yorùbá folktale narrative strategies into film thereby reawakening the memory of the viewers about the art of folktale and its moral teachings. The Yoruba video film İjàpá (Tortoise) and Àjàntálá shall be analyzed through the use of the theory of intertextuality.

\section{Conceptualization of Intertextuality and Adaptation in Film}

Many of the literary theories currently being used to evaluate works of art affirm that to a greater or lesser degree literary works maintain a link, an attention or affairs between themselves and other texts. This interest has brought intertextuality to the fore. Intertextuality is a word coined by Julia Kristeva ${ }^{3}$. Her notion of intertextuality refers to the literal and effective presence in a text of another text (Shakib: 2012:123). In such an approach, a text "is a permutation of texts, an intertextuality in the space of a given text, in which several utterances, taken from other texts, intersect and neutralize one another." (Allen 2000:35).

The core idea of the theory is that texts, such as novels, films and plays are always related to other texts in a way that produces multiple meaning (Yamasaki2011:2). Discussing intertextuality in film, Bazin 4 , says there is no doubt that all films were, in principle, works of authors who at a certain time and with certain technical and aesthetic means had managed to create certain distinctive cinematic art work (Barthes,1957). Most of Shakespeare's works such as Macbeth, Romeo and Juliet and Akínwùmí İsọlá's books Efúnsetán Ańiwúrà and Ó le kú as well as Chinua Achebe's Things Fall Apart and Arrow of Gods, Fémi Oșofisan's Morountodun, Wole Soyinka's The Lion and the Jewel and The Trials of Brother Jero and some Yoruba historical plays like Lísàbi Agbòngbò Àkàlà, Fábùmi Òkèmésí, The Trials of Àfọjá and others have been adapted to films.

3 Julia Kristeva is a French linguist who is understood to use the term Intertextuality in "Word, Dialogue and Novel" (1966) as written by Al faro, Maria Jesús Martinez (1996) 
Owóẹyẹ (2008:8) says 'intertextuality dwells a lot on the text and its link with other texts all around (the theory) itself coming on the heels of new criticism and points that meaning can be got only by relating a text to others'. While adaptation is in consonance with intertextuality in that an adapted text is linked to the source and some others, it departs in that it believe on looking eternally beyond the text(s) for meanings.

Commenting on adaptation, Hutcheon (2006:6) explains that adaptation is a form of intertextuality experienced differently by each reader. In creating a film of his own, a film script writer has many sources available to him. On the one hand, he composes an entire new work, devoid of any influence from a previous writer. In this case, his inspiration may come from history, myth, his society, or pure fiction. It is possible for a writer to fashion a film script out of any of these. On the other hand, a film script writer may work from an existing material. There are many things a writer can decide to do with an existing work. He may do such second-hand jobs as adaptation, limitation and translation.

Adaptation in literature is any change effected on the original piece of writing to bring out another improved version of it (Owóẹyẹ 2008:12). As a literary process, adaptation essentially entails altering, modifying or recreating a work of art from one source to new surroundings. The implication of this is that the adapting author only uses the existing material as a means of passing his message across in his own way. A cogent point about adaptation is that it takes an existing work into another environment in a manner and language in which it can be appreciated most.

What is obvious is that the adapting film script writers/ producers have their own vision of man and society; they have their ways of expressing such visions and commitments in their works, even when they consciously imitate the works of earlier playwrights/ novelists/ film script writers. The end result is a notable contribution to the development of the Yorùbá home video in reshaping the society.

\section{What is Folktale?}

Folktale is one of the features of oral literature. Yoruba society entertains and educates itself especially the children, through folktale. Folktale is a narration or story telling targeted at children for moral rejuvenation and entertainment. It is a fictitious story narrated at night by elders to children to guide them towards desired habits and also to entertain. It is one of the major aspects of the oral tradition in Yorùbá society. It is the telling of story by narrators to instruct the young and teach them to respect the dictates of customs. As a result, a large body of moral instructions, of societal values and norms are preserved for posterity. This aspect of oral literary form is portrayed in the two films used for this study. Folktale could also be described as the exciting pathway into Yorùbá life. They provide entertainment and relaxation for people after the day's work. With different stories, and mostly with the tortoise as the hero, young people are taught to understand the basic principle which upholds the primacy of the community. No matter how wise or great, one cannot be wiser or greater than one's community. This forms the basic ideology that generates Salami's characters. He uses the story of the tortoise to teach morals. Generally, Yorùbá folktales are as much didactic as they are entertaining, structured with begin- 
nings, conflicts, and resolutions. Every narrator (Emenyonu 1978:2) indicates, 'was for his audience, the educator, entertainer, philosopher, and counsellor. He entertained as he instructed and endeavoured to make values and beliefs portrayed in the tales come alive'. The stories are repeated to many generations but adapted to suit the perceived changes in every age and place.

Film is a powerful tool for the transmission of cultural value and the Yorùbá cherish their cultural heritage. This is the reason Adébáyọ Sàlámì and Kẹmi Afọlábí choose to use the narrative strategies of Yorùbá folktale to instil and teach audiences moral lessons and also bring to our memory the act of moonlight tales of our forefathers. Diawara (1988:6) also notes that "nothing can evolve out of nothing, and as such, an African cinema can only evolve out of a repertoire of its oral traditions such as myths, legends, folktales and other folk modes". He states further that when African film is examined, one sees that all directors resort in different ways to oral story telling forms. Akinyemi (2007: 123) corroborates Diawara as his paper centres on how Akinwùnmi İsọlá incorporates various Yorùbá oral genres (folktale inclusive) into two Yorùbá literary texts before adapting them into films to show that oral literature has a continued vitality for modern day society. He centres the paper on the playwright's use of elements of oral literature in depicting the socio-political realities of contemporary Nigerian society (Akinyemi, 2007:123).

This study is concerned with two Yorùbá video films, İjàpá and Ajàntálá. Both films are spectacular, especially in the choice of the script writer to give the film names familiar with Yorùbá folktales depicting the social vices in contemporary Nigerian society. This paper therefore, examines how the filmmakers use their creative ingenuity to reawaken and preserve Yorùbá oral literary forms, 'folktale' while dealing with socio-cultural issues in their country.

\section{Analysis of 'Ìjàpá' film produced by Adébáyọ Sàlámì.}

The creative deployment of folktale in 'İjàpá' film is set within the world of the Nigerian urban elite. The world is rich, cosmopolitan and corrupt. Advanced fee fraud- a modern way of stealing through different tactics, employed by the Santos family to defraud people, is presented.. The film explores in detail this and other moral failures of the elite. Transgression dominates the film which places characters in situations where everyday moral etiquette is outrageously flouted. Mr Santos is compared to İjàpá, his wife, Mrs Santos compared to Yánníbo (Tortoise's wife) while Adémípọ, their son is compared to İrère (Tortoise childs' name). He is considered to be wiser and more intelligent than his parents. This is confirmed in the opening glee song in the narrative which is the actual representation of the story.

Mẹ́ta nìyekan alábahun

Ijjàpá ni baba tó n soko yánníbo

Irère lomo wọn, tọ tunsojí juàwonòbi

Omo eye leye ń jo

Ogbọ́n ju agbara lo

Ijàpá you wise o 
Tortoise family are three in numbers

Tortoise is the father, husband to Yannibo

Irere is their son, who is wiser than his parents

A bird would always resemble her parents

Wisdom is greater than power

Tortoise, you are wise

The song is also rendered at intervals in the film whenever Adémípọ is ready to carry out another fraudulent act. Storytelling is an active exchange in which the audience participates with song and response. The interlude song is rendered at intervals to remind the audience of the tale while they participate in it which serves as a link to the original story of 'İjàpá' tales. All the attributes and characters of the tortoise, a trickster animal, are projected on to the Santos family.

There is an intertextual link between the film 'İjàpá' (the tortoise) and the Yorùbá trickster tale whose figure is İjàpá 'tortoise' "as Adébóyè Babalọlá, 1979” presented tortoise in the different tales in his book “Ákójopọ Àlọ İjàpá Apá kinnní àti ikeji”. The film is an adaptation of different tales about the tortoise in the above-named book and it has an intertextual link with the archetypal language of oral narratives, showing Mrs Santos singing the praise poetry for her son which resembles the tortoise' praise poetry.

Omo tí wọ́n binílé ogbọ́n

Tó fi òja òye pọn,

Tó tún mu omú ìmò

Àkànbí, omọ ogbọ́n jagbára lọ.

A child born in wisdom home

Wrapped with the girdle of understanding

Who sucked knowledgeable breast

Àkànbí, son of wisdom is greater than power

İjàpá oríkì goes thus:

Ijàpá tìrókò ọo Yánníbo

Olọgbọ́n èwé, onikùn òtè

A-fogbọn-gbara-rẹ lợọ búburú

A-fàmọjù dera ẹ nígbèkùn

İjàpá omo Arìnlọṣin

İjàpà tìrókò, Yánníbo's husband

Full of craftiness, shrewd in nature

Who craftily delivers himself on a bad day

Whose 'too know' always put into bondage

Tortoise, child of Arìnlọ́sìn 
The praise poetry of the Santos family is similar to ijapa's (tortoise) own. Adémipọ is endowed with trickish wisdom just like the tortoise. This further corroborates the fact that the producer of the film adapted the Yorùbá folktale of the tortoise.

A trickster figure is a devious animal or character that employs its cunning to protect itself against much larger and more powerful animals and whose pranks usually cause trouble for another character. Tale 1 goes thus:

Ijàpá àti Àdàbà jo dá oko kan (see Babalola, 1973: 8-10 for the full version) İjàpá (Tortoise) and Àdàbà (Dove) cultivate the same farmland (my translation and summary of the story)

İjàpà and Àdàbà were intimate friends. They did everything in common and unison but married different women and lived in different houses with their children. The two friends join hands to cultivate several hectares of farmland. They planted different crops like cassava, corn yam and vegetable. As harvest time neared, the two of them looked forward to making money out of it. But İjàpá and his family always come in the night to harvest any ripe crop, eat and sell and the following morning, he would be the first to shout that thieves have come to steal their harvest. İjàpá continued this dubious act until the day Àdàbà decided to employ the service of a hunter without the knowledge of İjàpá. The hunter set a trap in the night. When ìjàpá and his family came again to steal in the night, the trap caught him while balancing harvested yam and other farm produce on his head. His wife and children ran away and ijàpá died before the hunter could get to the trap. This was how covetousness and breach of agreement/contract and unfaithfulness led to ijàpá's untimely death. Àdàbà inherited all the remaining harvest.

The above tale corresponds with the shady deals of the Santos family when in the film, Ijapá, they dupe a group of four boys on the issuance of fake passport and visa. Mr. Santos perfects this arrangement and even poisons one of the boys who came to collect the passport and visa. The boy later gets home but dies. His colleagues avenge his death by hiring assassins to destroy the entire Santos family. Luckily and unfortunately, it is only the mother, the assassin kills at home but later goes for the father and kills him at the burial ceremony of his wife. The story has a link with tale1: Tortoise and the Dove. Greediness, dubiousness and breach of contract are the tortoise characteristics that are revealed in the Santos suspect family business. Tortoise lost its life as did Mr and Mrs Santos due to their dubious character, unfaithfulness and breach of contract. The intertextual link is that the Santos' family are killed by the victims of their fraud just like tortoise (ijàpá) in the above tale. Salami uses the above Yorùbá tale to condemn the different acts of corruption and fraudulent practices in the Nigerian society and also to warn against such acts as there is reward for every deed.

Another feature of the trickster İjàpá (Tortoise) is that it goes away gloating and unpunished, though in some tales there is a reversal, and the trickster falls prey to the mischief he started (Cristina, 2009). This figure of mischievous description is characterized by rule-breaking, lies, theft and shape-shifting. The tale below explains these characteristics and compares it with what happens in the film, ijàjá. 
Tale 2: İjàpá (Tortoise) and Ìgbín (Snail) dẹ ọsọ́ (set trap) (see Babalọlá 1979, 108-111 for the full version. (My translation and summary of the story)

İjàpá (tortoise) and İgbín (snail) were intimate friends. They do things in unison. Igbin married his daughter to Ijapa. Igbin knew that Ijapa was covetous in character because he always chose the best and the biggest gift anytime they were given gifts. The snail was looking for a way to show the tortoise that covetousness is a bad characteristic. One day, tortoise informed the snail that some animals had been coming to steal his harvest on the farm. He mentioned pig and antelope and begged the snail to join him in setting a trap for these big animals. The tortoise said this would give them the advantage of obtaining free meat and serve as deterrent to other animals. The snail accepted. On the first day, the trap caught a big rat. The tortoise advised the snail to take it away because by tomorrow, the trap would catch a bigger animal. He said this statement due to his covetousness. The snail took the animal home and on the second day, the trap caught an antelope. The snail encouraged the tortoise to take the antelope home on a strong note that he was sure the trap would catch an animal bigger than the antelope the following day. Again, the tortoise due to his covetousness asked the snail to take the antelope home, saying he would wait till the following day for a bigger animal. So, this trick went on until a day when the trap caught an elephant. The snail as usual encouraged tortoise to call his family member to assist him in carrying the animal home with an assurance that that the trap would catch òràn (crime), a bigger animal the following day. The tortoise declined carrying the elephant home. He preferred to take òràn (crime) the following day thinking that was a name of another big animal. The snail went home and called his family members to help carry him the elephant home. At midnight, the snail sought the help of three able- bodied men to carry the trap and set on the route the princess takes dailyto take her bath at the stream early in the morning. The following morning, the princess led her entourage to the river. She was caught by the trap and all her entourage ran away, shouting and asking for the person who set the trap. They were crying and saying that the person has committed a big crime ( ta ló dá òrànńlá) İjàpá was still sleeping when he heard some voices saying (ta ló dáràn) who committed this crime? He did not listen very well; he jumped up from his bed and went outside to announce that he was the one that set trap to catch òràn (crime). The security men arrested him and took him to the king who pronounced that the tortoise should be killed.

The tale reveals that ijàpá is a film text that took off from extant Yorùbá folktale, Santos' son, Adémípọ̀ who is also referred to as İrère (ijàpá son's name), according to the interlude song of the film, is wiser than his parents. He changes the advanced fee fraud business to the production of fake wine and drugs. He joins the Association of Manufacturers to discover all their secrets about the production of drugs and later joins the Association of fake drugs producers to apply the knowledge of what he has learnt in the original association to the fake one. Sàlámì Adébáyọ̀, the producer of İjàpá film brings this attitude to the fore through one Mr. Bọdé who is a member of the two associations of manufactur- 
ers of wine, that is the fake and the original. He specializes in producing fake wine. The fake wine according to the utterances of his wife has killed many people but fate soon catches up with him as his only son takes the wine and dies. This is taken from tale 53 'Tortoise and the Snail set trap' where covetousness leads ijàpá to an untimely death as he was caught in his own trick like Mr Bọdé. Mr Bọdé was supposed to have heeded his wife's advice to stop producing fake wine but did not, just as how the tortoise had failed to take to the snail's advice to take the elephant home. The fake wine killed his only son due to his covetousness while tortoise was also killed due to covetousness. The two of them were caught in their tricks. This makes Mr Bode reveal the secret of the fake association of manufacturers to the body that controls the production of fake products, the National Agency for Foods and Drugs Administration and Control (NAFDAC). Adémípọ is later arrested and charged in court on the count of the production of fake drugs and wine that has led to the death of many people. While in the custody of the security agency (the court did not grant him bail on the case of producing fake drugs which has killed many people), he feigns sickness and is granted bail on the presentation of a fake medical report. Immediately after his release, he dabbles into another act of mischief at the mercy as he is of passions and appetites; he possesses no values and morals. He absconds alongside his two guarantors who are his accomplices. He runs to a village, changes his facial appearance, his way of life and presents himself to the village head as a researcher who wants to know whether their land is fertile or not to plant some seeds which will be exported later. He is given a piece of land for the agricultural production. Akinyemi (2007: 126) opines that folktale is an effective traditional educational tool in Yorùbá society. Sàlámì integrates the act of a trickster into the film to teach society the moral lesson about the penalties for greediness just like the tortoise, a defrauder would always be caught in his own web, $\mathrm{Mr}$ Bọdé and Adémipọ in the film, İjàpá.

Tale 3:İjàpá yá owó àyásan lọwọ́ ẹlẹdẹ (Tortoise borrowed money from the pig) can be likened to the connivance between Adémípọ̀ and Tólání his wife. It has an intertextual connection with the tale where İjàpá connived with his wife so as not to pay the money the pig had lent him.

Tale3 ((İjàpá) Tortoise borrowed money from (ẹlệdẹ) Pig. (see Babalọlá 1979, 61-65 for the full version. (My translation and summary of the story)

Once upon a time, there was tortoise and the pig who were intimate friends. The pig is known for hard work and wealth but he is hot tempered. He easily gets annoyed on trivial matters. He is always lending money to neighbours and friends. The tortoise cannot do without seeing the pig on daily basis due to his covetousness by collecting money from pig at all times. One day, Yánníbo, tortoise's wife gave birth and there was no money to take care of her and have the naming ceremony. Tortoise went to the pig to borrow two hundred naira with an assurance that he would pay the money back as soon as his farm produce is ready for harvesting and sales. The pig lent him the money. When it was time for harvesting and sales, tortoise harvested and sold all the farm products but refused to pay pig his money. The pig sent a messenger 
to tortoise for his money, he promised to pay back in seven days. The pig accepted and waited. On the sixth day night, tortoise called Yánníbo his wife and gave her instructions to follow the following morning because he knew the pig would surely come for his money.

Tortoise says:

"Yánníbo, listen to my instruction on how we can be delivered from paying the pig. Tomorrow morning, sit at the door step and watch for pig's arrival. As soon as you see the pig, run inside and turn me upside down. Put my back on the floor, take pepper and start grinding it on my chest. Do not answer the pig at all. Just pretend that if you do not hear whatever he is saying. I know he is hot tempered; he would throw away the grinding stone which you bought at the rate of two hundred and fifty naira. I will walk in and pretend as if I am not the grinding stone he threw outside. He must look for our grinding stone before we can pay back his money. You must not laugh at all so that he will not be aware of our plan".

İjàpá, the tortoise of the Yorùbá tribe of Nigeria, West Africa, is shrewd, greedy, sometime wise, conniving, indolent, ambitious and exhibitionistic (Cristina (2009). This is very much Adémípọ̀s character in the film İjapá as revealed in the above tale. While in the village; he connives with his wife, Tọlání to declare his death, having taken out a life insurance policy before travelling to the village. Tọ́lání announces the death of her husband and also presents poster containing her husband's picture and fake death certificate to claim the money from the insurance company. She knows about her husband's escape but pretends not to know. She always visits her husband in the village to give feedback of all their mischief.

In the film, İjàpá, Adémipọ meets another waterloo when one of the sons of the village head who is an official of the insurance company in charge of his life insurance visits his father and sees Adémípọ. He goes back to the city to inform the security agencies. Adémípọ is later arrested with his wife in the village and charged to court on the count of murder and obtaining money under false pretences. The Judge, while delivering his verdict after Adémípọ confesses that his parents taught him to be a fraudster, says the proverb 'Oggbọ́n tí Alábahun bá gbọ́n èyìn ló fi ń tọggbín. (With all the wisdom of 'alábahun' another name of tortoise, snail will always lead it) still making reference to tale 2 mentioned above. To corroborate his judgement, the judge also makes reference to another tale 4 and he says "the tortoise wanted to put the entire wisdom of the world in a gourd and climb the palm tree. It was the hunter that told him to put the gourd on his back before climbing the palm tree.

Tale 4: Ijjàpá kó gbogbo ogbọón ayé sinú kèngbè. (see Babalola, 1973: 16-19 for the full version) İjàpá (Tortoise) keeps all the wisdom of the world in a gourd (my translation and summary of the story.

Ijapa (tortoise) was a very wise animal. His kind of wisdom is filled with cleverness, cunning and subtlety. He loved praising himself and always boasted of his wisdom 
in the presence of other animals and human beings. He thought to himself that he would be the wisest if he could gather all the wisdom of this world and secretly keep it somewhere so as to become the wisest being on earth. This would give him the opportunity to give and sell wisdom to whomsoever he wanted. Ijapa started gathering all the wisdom from town to town and kept in a gourd with a cover. When he had gathered all the wisdom that could fill the big gourd from different towns, he covered it and went back to his town. When he got to home, he was happy to have gathered all the wisdom of this world. He tied a rope on the gourd and wanted to keep it on top of the araba tree. The rope was hung around his neck, dangling on his chest. The gourd on his chest prevented him from climbing the tree. He tried all he could, but to no avail. He was sweating profusely from morning till night while trying to climb the tree. A hunter passing by the araba tree saw the tortoise and told to him to turn the gourd to the back before climbing the tree. The tortoise explained what he had been trying to do and the hunter replied that it was not wise to turn the gourd to the front because it will be difficult to climb the tree. Tortoise heeded his advice and climbed to the top of the tree. When he got to the top, he was sorrowful for he realised that he was not the wisest on earth.

The judge said it was then that the tortoise realised that he was not the wisest in the whole world and ends the verdict with the story and said 'nobody is a repository of wisdom.' Adémípọ is sentenced to life imprisonment while his accomplicé, who is also his wife, Tọ́lání is sentenced to ten years. Salami reiterates this story through the judge to warn fraudsters and other corrupt people to desist from their evil acts because someone who is wiser than them will one day outsmart them.

The intertextual factor embedded in the setting of the film 'Ijàpá' (Tortoise) provides an example of implicit intertextuality. The film's setting is actually adapted from the different tales of the tortoise as presented by Àdébóyè Babalọlá in his collection of the Tortoise tales, which contributes well to the narrative strategy of the work in that the focus on a limited space helps the character relations look more dramatic than is the case in the actual different storyline / tale about the Yorùbá trickster animal, the tortoise.

There is an important intertextual element hidden in the title. The title of the film 'Ijàpà' was taken from the different tales about the trickster animal of Yorùbá folktale. The use of the title is a clue to the fact that Sàlámì is referencing the classic Yorùbá folktale. This is what Sàlámì enjoys and stresses in his film making; that is why he keeps repeating the interlude song at intervals just as a Yorùbá story teller would do while telling a story to young children. Sàlámì's adaptation of a Yorùbá folktale into film is to reveal his philosophy about the rot in the society, thereby calling for restructuring and change and at the same time reawakening the memory of the viewers of the art of storytelling in the Yoruba society and Nigeria in general. 


\section{Analysis of Àjàntálá produced by Kẹemi Afọlábí}

Àjàntálá is a well known story amongst the Yorùbá folktales. Daniel Fágúnwà in his book 'Ògbójú Odẹ nínú Igbó Irúmolè, which was translated into English by Wọlé Șóyínká as 'The Forest of a Thousand Demon' makes the myth or tale about Àjàntálá more prominent amongst the Yorùbá and the literary world in general. Whenever one wants to speak about a vicious character, Yorùbá people would call the person 'Àjàntálá'

On seeing the title of the film on the jacket, one would jump to a conclusion that the film must have something to do with the Yorùbá popular folktale 'Àjàntálá'. Different stories about Àjàntálá, Fágúnwà (1968) and Tútùọlá (2004) reveal that Àjàntálá is a turbulent / terrible child with vicious character. Kẹmi Afọlábí's film titled Ajàntálá is also about a terrible child with vicious character. There is an intertextual link between the story in the film and the account of the above-named author. Unlike Adébáyọ̀'s 'ijàpá', which begins with different tales and the character of the tortoise, Afọlábí's 'Ajàntálá' is a little bit different. Ajàntálá is a short story written in a very interesting manner consisting of five parts which are interconnected to each other in the novel, 'Forest of a Thousand Demons'. The film blends perfectly into the narrative formula of the Yorùbá oral rendition. This story is about Oyíntọmmíwá, a daughter to Àbẹkệ asínlệkẹ̀ (a bead maker) a beautiful fair lady. Her mother makes beads for the queens and king. Her mother died mysteriously but before she died, she has handed over Oyíntọmíwá to the king to take care of, unknown to the queens. After the death of her mother, Oyíntọmíwá moved into the palace to live with them. The King developed an interest in Oyíntọmíwá and believed in the prophecy that says he would have a child through another woman and it is the child that would make way for the two queens who are barren to conceive and give birth to children.

The films talks about the futility of life when Oyintọmìiwa's mother appears to her in a dream and calls her Àjàntálá. Oyintọmíwá's mother later died. The woman while handling over her daughter to the king speaks about the futility of life. She told the king that her daughter is mourning at home and that is the reason she did not follow her to the palace. She speaks further:

Ìwơniba là ń dárò eni tó ti kú

Àwon tí ń be láyé ni kí wọn sèdárò ara won

Kábiesí, ayé le gan an, ení bá rántí òfò

Ó ye kó mọ póun ò ní de nǹkan mọwó kokoko

Béeyàn bá ránti ikú Kábièsí, yó sinmi oge síse

ojọ kan ń bò ta ó sù tá ò ní jí mó

A ó gbé owọ, kò ní se é gbé

Àgbọn isàlè yóo dè silè

Enu tá a fi jàgùntàn, tá a fi ń jewuré

Nigbà wọn bá de onitọhún lókùn tán, tí wọn gbé e lo

Wọ́n ó máa ní enire lọ. Ló bá tán.

One should not lament too much over the dead

The living should lament over themselves 


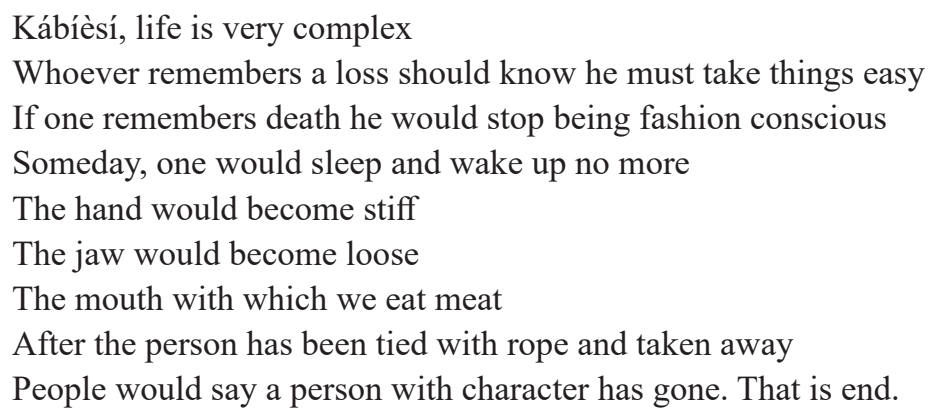

The script writer incorporates the above excerpt to teach a moral lesson on the futility and vanity of life.

Àjàntálá is known for his vicious and turbulent behaviour. In Fagunwa (1968:110), the Ifá priest called upon to divine and sacrifice for Àjàntálá's behavioural change says further after facing a terrible fight with Àjàntálá that:

"On that child's affair, never again! It is a very brute of a child: since the day I came

Into this world I have never encountered that which I met today. What did he not

do to me! He beat me till I was near death; he punished me till I was near invalided.

He pulled me and dragged me around...

It was recorded in Fagunwa (1968) that Àjàntálá become a problem until the mother could bear it no more and took to the turbulent child into the bush and ranaway from him. Meanwhile, Afọlábí in her own film adaptation integrates Àjàntálá's turbulent behaviour to her story by making use of Àjàntálá's mother image while punishing the people who cheated her mother.

There are problems and conflicts within the king's household about Oyíntọmmíwá. The queens are jealous of her because they discovered that the king is interested in her, so also the king's younger brother. There is conspiracy and this leads to Oyíntọmíwá's excommunication from Pàràkòyí town. She later goes to live in the forest until it is time for the delivery of her baby and she delivers a baby boy whom an ìrókò tree troll or gnome give some supernatural powers to, which he uses to punish his mother's offenders.

The intertextual difference between the stories is that Fágúnwà's Àjàǹtálá spoke immediately he was born but Afọlábí's Àjàntálá speaks after some days he was born. Afọlábí in her adaptation of Fágúnwà's novel drifts from this but all the same, she still makes us understand that her own Àjàntálá is also a turbulent child. The story teaches that conspiracy and wickedness are bad characteristics that must not be practiced amongst human beings.

\section{Conclusion}

We have tried in this paper to discuss the preservation of folktales and the reawakening of oral literature material through the use of adaptation into films. Due to modernisation and civilisation Yorùbá elites do not tell folktales as was the practice in the old days but these films producers have been able to tell folktales through their adaptations. Adapted 
works often carry the stamps and trademarks by which the adapting author is known. An author's ideas, philosophy, language, mode and other peculiarities of his writing are always reflected in the adapted work. In this regard, it can be observed that the two films examined 'İjàpá and 'Ajàntálá' are adapted from folktales texts. The creative ingenuity of Sàlámì and Afọlábí is revealed with the theory of intertextuality. The folktale stories that herald the events in the films have been proved as intertextual stimulus in the building of the films. One cannot doubt it that the films are a playback of different manifestations of societal ills. The films mirror the society and call for the restructuring of human characters, thereby teaching moral lesson which form the endnotes of all folktales especially in Yorùbá Southwest of Nigeria. Incorporating the Yorùbá folktale into film is a way of revitalising the memory of the viewers about the important lessons of life. Ordinarily, they might not be able to lay hands on folktale books due to a poor reading culture and pressures of life but watching of film is used to defuse tension and relax.

\section{References}

Adésínà, Foluke. "Film Content and Moral Rearmament in Nigeria", Operative Principles of the Film Industry: Towards a Film Policy for Nigeria." Jos:Nigeria Film Corporation. (1992) 169 - 178

Àkànbí T.A.”Moral Value of Yorùbá Moonlight Tales." in Open Journal of Modern Linguistics. Vol.4.2014, pp. 481- 486

Akinwumi Sesan. "Yoruba Folktales, the New Media and Post- modernism" in Khazar Journal of Humanities and Social Sciences. Vol.17,No.2.2014.pp.74-87. Accessed https://www.researchgate. net/publication/261959542_Yoruba_Folktales_the_New_Media_and_Post- modernism 22February 2016.

Akínyẹmí, Akintunde. "Yorùbá Oral Literature: A Source of Indigenous Education for Children." in Forms and Functions of English and Indigenous Languages in Nigeria. A festschrift in Honour of Ayọ̣ Bánjọ: eds. Kọ́lá Owólabí and Adémọ́lá Dasylva. İbàdàn. Group Publishers. 2004, pp 461481

Akínyẹmí, Akintunde. "Oral Literature, Aesthetic Transfer, and Social Vision in Two Yorùbá Video Films." in The Preservation and Survival of African Oral Literature. Research in African Literatures.Vol.38 no.3, Fall 2007. pp. 122-135.

Akínyẹmí, Akintunde. "African Oral Tradition Then and Now: A Culture in Transition." Centrepoint Journal (Humanities Edition) Vol. 14. no.1, 2011, 27-51,www.unilorin/edu.ng/ejournals/.../190. Accessed 28 January, 2016.

Al faro, Maria Jesus Martinez. Intertextuality: Origin and Development of the Concept" Atlanta, Vol.18, No.112, 1996, pp268-285

Allen, Graham. Intertextuality. London, Graham Allen Presses, 2000.

Babalọlá, Adeboye. Àkójọpò Àlọ İjàpá: Apá Kìnní. Jericho: IbadanUniversity Press Limited, 1979.

Babalọlá, Adeboye.ÀkóọopòÀộ̀jàpá: Apá Kejì. Jericho: IbadanUniversity Press Limited, 1973.

Barthes, Roland. Elements of Semiology ( trans, Annette Lavers and Collins Smith) London: Jonathan Cape, 1957.

Cristina, Ferreira Pinto "The Animal Trickster -An Essential Character in African Tales" in ETENMyths \& Fairy Tale. Accessed online on www.ETEN-online.org>dl_attachment TIG/ZMR 2009 (1) 0230983122 Accessed on4/1/2016

Diawara, Manthia. "Popular Culture and Oral Tradition in African Film" Film Quarterly, Vol.4No.3 1988, pp.6-14, fa.ucpress.edu>content DO1:10.2037/1212516 
Ellapen, Jordane Abner African Film: New Forms of Aesthetics and Politics. By Manthia Diawara in Black Diaspora Review 3(1), Winter 2012. Accessed on https://scholarworks.iu.edu $>$ download

Emenyonu, Ernest. The Rise of the Igbo Novels Ibadan, Oxford University Press, 1978.

Fágúnwà, Daniel. The Forest of a Thousand Demons: A Hunter's Saga (Wolé Sóyinká 's Trans) London: Nelson, 1968.

Franz Van der Puye "Media and the Preservation of Culture in Africa" in Cultural Survival Quarterly Magazine. June 1998.

Hutcheon, Linda. A Theory of Adaptation. New York: Routledge 2006.

Mgbejume Onyero "Film in Nigeria: Development, Problem and Promise in African Media Monograph Series, No. 7. ACCE. Kenya, 1989.

Ọárìnmóyè, Adeyinka."The Images of Women in Yorùbá Folktales" in International Journal of Humanities and Social Sciences Vol.3, no. 4, Special Issue -February,2013.pp 138-149 www. ijhssnet.com>journals> vol.3.no.4. Accessed 26 January, 2016.

Ọláyíwọlá, Abiodun. "Beyond Hollywood Formulas: Evolving Indigenous Yorùbá Film Aesthetics" Journal of Cross-cultural Communication. Vol.7.No. 2, 2011: 219-228. Accessed cscanada.net/ index.php/ccc/article/view/j.ccc.192367002011100702.075 26 January, 2016.

Owóẹyẹ̣, Omolara. "Adaptation in Modern African Drama" Unpublished Doctoral Dissertation Department of English,University of Ado- Ekiti, (Nigeria), 2008.

Shakib, Mohammed. "Inevitability of Arts from Intertextuality" International Journal of English and Literature. Vol.4. No.1, pp 1-5.Accessed http://www.academicjournals.org/article/articl.1389992_ shakib 28 February,2016.

Tutùọá, Amos. The PalmwineDrinkard and His Dead Palmwine Tapster in the Deads Towns. Abuja: Spectrum Books Ltd, 2004

Ureke Oswelled and Tomaselli Kenyan "From 'African Cinema' to Film Services Industries: A Cinematic Fact.” Journal of African Cinema Volume 9, Number 1. Pp 75-92. 2017.

Usman Joshua et al "Folktale as Material Resources for Movie Production in Selected Nollywood Movies".International Journal of English and Literature Vol.4.no.1 2013: 236-241. Accessed on http://www.academicjournals.org/journal/IJEL/article-abstract/097291A522828 January, 2016.

Yamasaki Rie "The Films of Mitani Koki: Intertextuality and Comedy in Contemporary Japanese Cinema. New Voices. Vol.4No.6 pp123-143. Accessed on http://newvoices.org.au/new voices/ media/JPF-New -Voices-Vol-4-06-mitani_yamasaki.pdf Accessed.28 January 2016.

\section{Videograhy}

Àjàntálá Dir. Oladele Matti. Olasco Films Nig. Ltd. 2015.

İjàpá Dir. Adébáyọ̀ Sàlámì. U-Bee Media Network/ Ejide Film Distributors.2011. 
